\title{
Egg trait variation in anchoveta Engraulis ringens: a maternal response to changing environmental conditions in contrasting spawning habitats
}

\author{
L. R. Castro ${ }^{1,2, *}$, G. Claramunt ${ }^{3}$, M. C. Krautz ${ }^{1,4}$, A. Llanos-Rivera ${ }^{1,5}$, P. Moreno ${ }^{3}$ \\ ${ }^{1}$ Laboratorio de Oceanografía Pesquera y Ecología Larval, Departamento de Oceanografía, ${ }^{2}$ Centro FONDAP-COPAS, and \\ ${ }^{4}$ Programa de Doctorado en Oceanografía, Universidad de Concepción, PO Box 160-C, Concepción, Chile \\ ${ }^{3}$ Departamento de Ciencias del Mar, Universidad Arturo Prat, Casilla 121, Iquique, Chile \\ ${ }^{5}$ Present address: Unidad de Biotecnología Marina, Faculdad de Ciencias Naturales e Oceanográficas, \\ Universidad de Concepción, PO Box 160-C, Concepcíon, Chile
}

\begin{abstract}
The Engraulis ringens distribution (4 to $\left.42^{\circ} \mathrm{S}\right)$ covers a wide variety of environmental conditions. We assessed the coping mechanisms used by this anchoveta in different spawning habitats, reporting differences in egg traits between populations off northern (Iquique, $20^{\circ} \mathrm{S}$ ) and southern Chile (Talcahuano, $36^{\circ} \mathrm{S}$ ) and throughout the spawning season. Eggs were smaller off Iquique, declined in size during the reproductive season (both populations), and inter-population differences persisted throughout the spawning season. Batch fecundity (eggs per batch per female) and relative fecundity (eggs per female weight) were lower off Talcahuano during the peak spawning months. Thus, larger eggs spawned in the southern population seem to be produced at the cost of a reduction in fecundity. The eggs also differed biochemically between the 2 populations; total lipids and triacylglycerides were much higher off Talcahuano. The biochemical composition (both populations) also changed throughout the spawning season, with higher lipids early in the spawning season (July to August) off Talcahuano. Hatching success decreased during the spawning season, and correlated positively with egg size and lipid contents. Environmental conditions differed markedly between spawning areas and from mid-winter to late spring. Off Talcahuano, the temperature and winter-time water column productivity are lower and turbulence is higher, while eggs are larger, lipid contents higher, and batch fecundity lower. This mechanism seems to facilitate survival of young offspring in the more adverse winter conditions off Talcahuano. These egg characteristics are determined by the adult female reproductive system, representing a maternal influence on the early life-history traits of anchoveta that might enable rapid changes in population densities in some years of improved habitat conditions.
\end{abstract}

KEY WORDS: Anchoveta · Engraulis ringens $\cdot$ Upwelling $\cdot$ Reproductive strategy $\cdot$ Egg quality · Lipids $\cdot$ Humboldt Current $\cdot$ Small pelagic fishes

- Resale or republication not permitted without written consent of the publisher

\section{INTRODUCTION}

Variations in egg size among populations located along a latitudinal gradient or during the spawning season have been reported for a number of demersal and pelagic fishes (Blaxter \& Hempel 1963, Bagenal 1971, Blaxter \& Hunter 1982, Thresher 1984, Chambers 1997). In general, larger eggs are spawned at higher latitudes, egg size tends to decrease as the spawning season progresses, and eggs produced in winter are larger than those spawned in summer (Ciechomski 1973, Clarke 1989, Claramunt et al. 1994, Rijnsdorp \& Vingerhoed 1994, Chambers \& Waiwood 1996, Plaza et al. 2002, Rideout et al. 2005). Whereas most authors have proposed egg size variability to be an adaptive trait to enhance offspring survival under different environmental conditions, others have suggested that egg size variation may be the result of the changing environmental temperature on the reproductive system of the adult females and, hence, not neces- 
sarily an adaptive genetic response to facilitate offspring survival in different environments (Daoulas \& Economou 1986). These hypotheses, however, are not usually tested. It has long been documented that larger eggs usually produce larger and more robust larvae, capable of searching larger volumes of water for food, evading predators more successfully, or growing faster. All these characteristics should reduce mortality under adverse environmental conditions (Marteinsdottir \& Steinarsson 1998).

Compared with egg size variation studies, less attention has been paid to assessing the quality of eggs in the field that originate larvae of different sizes. Variations in energetic content, the oil vesicle, or relative concentrations of different biochemical components in the eggs might play an important role in modulating the offspring's chances for survival (Chambers et al. 1989, Pickova et al. 1997, Rainuzzo et al. 1997, Lahnsteiner \& Patarnello 2005). The amount of lipid or protein reserves provided for the eggs or recently hatched yolk sac larvae, for instance, may modify the hatching success or the amount of energetic reserves available in different periods during the spawning season. Accordingly, the amount of reserves available to the eggs is expected to be correlated with the environmental conditions the larvae will face during the spawning season. These studies, although initiated some decades ago, have only recently been applied to wild small pelagic fish populations (Riveiro et al. 2000, 2004), probably due to advances in rearing methods and the simplification of biochemical techniques for aquaculture purposes.

Lipid and protein contents are reported to be important egg constituents and sources of stored energy in fish eggs. For lipids the triacylglycerides (TAG) is known to be a common form of energy, while, for protein, various free amino acids are important energy sources during embryonic development (Fyhn 1989). Phospholipids are also a major lipid component in the eggs of many marine fish species. Phospholipids are important structural components of membranes and an important source of energy during embryonic development in species with lower TAG contents (Tocher et al. 1985, Fraser et al. 1988, Rainuzzo et al. 1992). Larvae of many marine fish require highly unsaturated fatty acids (HUFA) of the n-3 series such as eicosapentaenoic acid [EPA: 20:5(n-3)] and docosahexaenoic acid [DHA; 22:6(n-3)] (Rainuzzo et al. 1997, Sargent et al. 1999). The fatty acid composition and hatching success are related, for instance, in different cod populations (Pickova et al. 1997). Proteins, the largest component of fish egg yolk, are transformed into embryonic tissue and are consumed to provide energy (Kamler 1992). Because of their apparent strong inverse relationship with embryonic development times, protein contents have also been suggested to be a key biochemical component in winter-spawned eggs of Sardina pilchardus off the Iberian Peninsula (Riveiro et al. 2000, 2004). For this small, winter-spawning pelagic fish, the higher protein concentrations in the eggs at the beginning of the cold months are thought to induce higher embryonic developmental rates. Thus, proteins could compensate for the lower temperatures that slow development in early winter. All these studies point to the existence of a relationship between the biochemical egg composition and the survival of young developing stages, thereby strongly suggesting a relationship between the environment and egg quality via maternal effects.

Along the Humboldt Current, the anchoveta Engraulis ringens is distributed from 4 to $42^{\circ} \mathrm{S}$; the environmental conditions in this latitudinal range vary drastically. Three major stocks are recognized along the Humboldt Current: off northern Peru (largest), off southern Peru-northern Chile (mid-sized), and off central Chile (smallest). Recent studies initiated to determine how the early life stages of this species cope with variations in environmental conditions (Castro et al. 2000, Hernández \& Castro 2000, Llanos-Rivera \& Castro 2004, 2006) have identified early life-history traits, such as egg size, larval size at hatching, yolk volume at hatching, and larval growth rates that vary along its latitudinal range. In particular, the egg size, larval length at hatching, and yolk sac volume of recently hatched larvae increase with latitude, and instantaneous yolk sac larval growth rates may differ between latitudes (Llanos-Rivera \& Castro 2006). Seasonal variations in size have also been reported in eggs of the southern $\left(36^{\circ} \mathrm{S}\right)$ anchoveta population (LlanosRivera \& Castro 2004). At this latitude, larger eggs are generally spawned in winter, and smaller eggs, in summer. At lower latitudes, however, no information is available on egg size variations throughout the spawning season of this species or on potential effects of egg size differences on the survival of subsequent early life stages.

In the present study, we report egg quality variations throughout the spawning season for 2 anchoveta populations located at different latitudes in the Humboldt Current $\left(21^{\circ} \mathrm{S}\right.$ vs. $\left.36^{\circ} \mathrm{S}\right)$. First, we assessed variations in egg sizes of recently spawned eggs $(<1 \mathrm{~d})$ in the plankton. Secondly, we determined whether variations in the biochemical composition of these eggs occurred during the season (total protein content, total lipid content, TAGs, cholesterol). Finally, we used rearing experiments carried out under natural temperature conditions to assess whether differences in hatching success occurred in eggs produced at different times during the spawning season that could suggest potential relationships among egg quality, offspring sur- 
vival, and environmental conditions during spawning. This approach seeks to combine disciplines such as adult reproductive biology, early life histories of fish, biochemistry, and basic oceanography within a conceptual framework of reproductive strategies.

\section{MATERIALS AND METHODS}

Field cruises, ichthyoplankton collections, and egg sorting. During the 2003 spawning season of Engraulis ringens, short (4 to $6 \mathrm{~h}$ each) cruises were carried out to the Talcahuano (south, $36^{\circ} \mathrm{S}, \mathrm{n}=15$ ), and Iquique (north, 20 $\mathrm{S}, \mathrm{n}=8$ ) spawning areas (Fig. 1). In 2004, 7 and 8 cruises were carried out to the northern and southern spawning areas, respectively. During each cruise, the ichthyoplankton was gently collected in short (3 to $4 \mathrm{~min}$ ) tows from the surface to $20-40 \mathrm{~m}$ depth, either with bongo or conical nets $(300 \mu \mathrm{m}$, oblique tows, with flowmeters to quantify volume of water sampled). Sea surface temperature was recorded at each station. Ichthyoplankton samples were

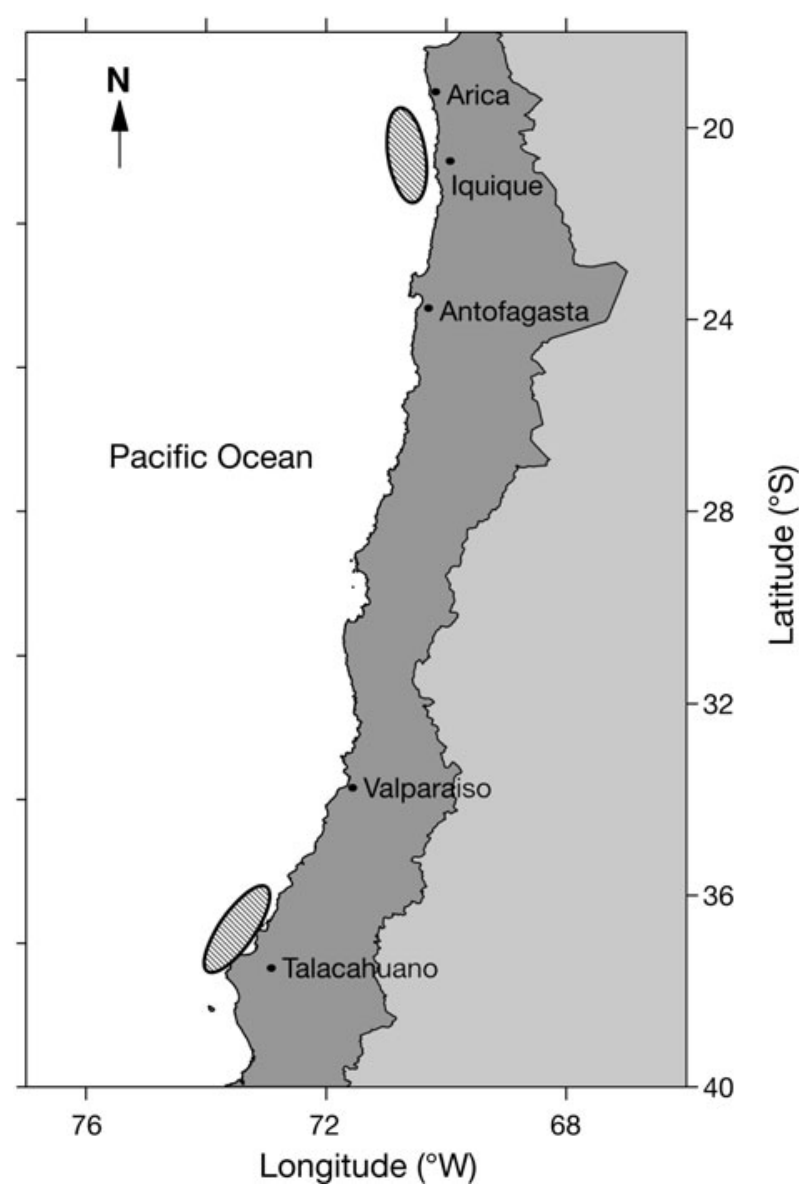

Fig. 1. Study areas off northern (Iquique) and southern (Talcahuano) Chile rapidly brought to the laboratory under temperaturecontrolled conditions and in the dark. Once in the laboratory, the anchoveta eggs were identified and quickly separated from the rest of the sample; subsamples were obtained for different analyses. Depending on their abundance, over 50 eggs per sampling date were preserved in $4 \%$ formaldehyde and then measured (widest and shortest axes) under a binocular microscope. The egg volume was estimated considering the egg to be ellipsoid in shape ( $V=4 \pi \times a \times b \times c$ ) 3). Another subsample was utilized for biochemical analyses and egg wet weight determinations on a $0.0001 \mathrm{~g}$ analytical scale. The wet weight (WW) was later transformed into dry weight (DW) by utilizing a conversion factor obtained from dry and wet weight measures of egg subsamples collected from each area (13 subsamples of 50 eggs each from the northern area; 20 subsampes of 50 eggs each from the southern area) during the sampling season (mean \pm SD DW/WW: north $=0.1273 \pm 0.026 ;$ south $=0.1061 \pm 0.0214)$. At least 50 eggs subsample ${ }^{-1}$ were used for protein and lipid determinations. These subsamples were separated into single vials and deep frozen at $-20^{\circ} \mathrm{C}$ for biochemical analyses. Finally, a fifth subsample of 100 one-day-old eggs was separated and incubated for hatching success determinations during 2004.

Biochemical egg composition. The biochemical composition of field-collected anchoveta eggs was determined throughout the spawning season for the southern stock in 2003 and for both stocks in 2004. The biochemical analyses included the concentration of total proteins and lipids (total lipids, TAGs, cholesterol). The analyzed samples consisted of recently fertilized eggs (prior to embryonic development); these eggs were younger than $1 \mathrm{~d}$ old at the environmental temperatures of collection (Stages 1 to 4 after Fisher 1958). Because protein and lipid contents per egg should co-vary with egg volume (i.e. $\mu$ g protein egg $^{-1}$; $\mu \mathrm{g}$ lipid $\mathrm{egg}^{-1}$ ), to compare the biochemical content of the eggs between populations and among months avoiding the effect of egg volume variability, all the biochemical compounds were standardized to egg dry weight (i.e. $\mu$ g protein $\mathrm{mg}^{-1}$ egg $\mathrm{DW}_{\text {; }} \mu \mathrm{g}$ lipid $\mathrm{mg}^{-1}$ egg DW).

Protein content: Anchoveta egg subsamples were macerated in PBS (phosphate-saline buffer; $10 \mathrm{mM}$, $\mathrm{pH}$ 7.4) using a glass tissue homogenizer. Each tube was centrifuged at $6600 \times g$ for $5 \mathrm{~min}\left(4^{\circ} \mathrm{C}\right)$; the supernatant was removed, aliquoted, and frozen at $-20^{\circ} \mathrm{C}$. Total fish egg proteins were determined after Lowry et al. (1951). Briefly, a $100 \mu \mathrm{l}$ aliquot of supernatant and $\mathrm{NaOH} 1 \mathrm{M}$ was added to vials of $1.5 \mathrm{ml}$, and incubated for $30 \mathrm{~min}$ at room temperature. Then, we added $1 \mathrm{ml}$ of Lowry reagent, incubating this for $10 \mathrm{~min}$. Finally, we added $100 \mu \mathrm{l}$ of Folin Ciocalteu's Phenol Reagent 
(1:6) and incubated this for $30 \mathrm{~min}$. Absorbance of each sample was measured in a spectrophotometer at $490 \mathrm{~nm}$.

Lipid content: Egg subsamples were macerated in PBS $10 \mathrm{mM}$ (pH 7.4) using a glass tissue homogenizer. Macerated eggs were transferred to $15 \mathrm{ml}$ glass tubes for analysis. Lipid extraction was performed after Bligh \& Dyer (1959). Accordingly, the solvent proportions were 0.8:1:2 (water:methanol:chloroform). After adding the solvents, the tubes were centrifuged at $1400 \times g$ for $5 \mathrm{~min}$ to facilitate phase identification. The chloroform phase was transferred to previously weighed glass vials. Samples were filtered through glass wool to remove any impurity. Glass vials were placed over a thermoblock at $36^{\circ} \mathrm{C}$ to avoid humidity accumulation. Chloroform was completely evaporated by bubbling $\mathrm{N}_{2}$ through the sample. Vials were chilled on silica gel to avoid humidity and weighed on an analytic balance (sensitivity: $0.1 \mathrm{~g}$ ). Vials were kept frozen at $-20^{\circ} \mathrm{C}$ until further analysis.

Triacylglycerides (TAG) and total cholesterol: The dry lipid sample was reconstituted with $300 \mu$ lisopropanol p.a. (Merck). Aliquots of $10 \mu \mathrm{l}$ were obtained to determine TAGs and total cholesterol through enzymatic and colorimetric reactions. TAG determinations were performed using an enzymatic kit TG PAP 150 (bioMérieux). Cholesterol was determined using an enzymatic colorimetric kit CHOD-PAP (Spinreact).

Hatching success: The egg subsamples collected in the field on each date were used for experimental setups (2 replicates, 11 glass flasks with 100 eggs each, maintained in a thermo-regulated bath). The $1 \mathrm{~d}$ old eggs that were suspended in the incubation flasks were incubated in a 10:14 h light:dark photoperiod at the in situ seawater temperature. Every day one-third of the water content of the flasks was replaced. The number of eggs hatched was determined by checking twice daily from the second day on and until at least $2 \mathrm{~d}$ after egg hatching should have occurred at the temperature utilized. The expected hatching time was estimated following the respective temperaturedependent models developed for anchoveta eggs for Chile's northern (Soto et al. 2005) and southern (Tarifeño et al. 2007) stocks.

Batch fecundity. From both spawning areas, batch fecundity was estimated during August 2003 and 2004, based on hydrated females using the gravimetric method described by Hunter \& Goldberg (1980), which excludes females with new postovulatory follicles as determined from histology. The oocyte counts were carried out on 3 ovary sections (front, medium and posterior) of about $0.2 \mathrm{~g}$ each, from which at least 100 hydrated oocytes were observed. Batch fecundity was estimated as the average of these 3 subsamples. While in the northern region 99 and 96 females were analyzed in August 2003 and 2004, respectively, in the southern region, 100 and 96 females were analyzed during the same months and years.

Environmental conditions. Daily sea surface temperature records (January to December) were obtained for both areas from tidal gauge stations operated by the Servicio Hidrografico y Oceanografico de la Armada (SHOA) located off Talcahuano and Iquique. Daily mean wind data (direction, intensity) were obtained from stations operated by the Dirección Meteorologica de Chile (DMC) at the local airports Diego Aracena (Iquique) and Carriel Sur (Talcahuano). The wind data were utilized to estimate a turbulence index $\left(\mathrm{m}^{3} \mathrm{~s}^{-3}\right)$ and the predominant south and north wind components, which induce upwelling and the seaward Ekman transport of eggs and larvae from the coast (south winds) and shoreward egg and larval transport and downwelling at the coast (north winds).

\section{RESULTS}

\section{Intra-seasonal variations}

In September 2003, the eggs from the northern population were larger than in other months; otherwise, egg sizes in both areas tended to decrease from the beginning to the end, as revealed by the significant $(p<0.001)$ and negative slopes in the regressions between egg volume and month of the spawning season in both areas (Tables 1 \& 2, Fig. 2).

In 2003, the number of biochemical determinations throughout the spawning season allowed statistical tests comparing monthly mean values of protein, lipid, TAG, and cholesterol in the eggs at the beginning (July/August) versus the end of the spawning season (October/November) for the southern population. For

Table 1. Engraulis ringens. Mean volume $\left(\mathrm{mm}^{3}\right)$, standard deviations, and number of anchoveta eggs measured (in parentheses) off northern (Iquique) and southern (Talcahuano) Chile during the winter spawning seasons of 2003 and 2004. -: no data

\begin{tabular}{|c|c|c|c|c|}
\hline \multirow{2}{*}{ Month } & \multicolumn{2}{|c|}{2003} & \multirow[b]{2}{*}{ North } & \multirow[b]{2}{*}{ South } \\
\hline & North & South & & \\
\hline Jul & $0.29 \pm 0.02(40)$ & - & $0.29 \pm 0.03(162)$ & $0.33 \pm 0.03(407)$ \\
\hline Aug & $0.27 \pm 0.02(70)$ & $0.38 \pm 0.03(100)$ & $0.29 \pm 0.03(57)$ & $0.33 \pm 0.03(410)$ \\
\hline Sep & $0.31 \pm 0.03(43)$ & $0.36 \pm 0.03(200)$ & $0.28 \pm 0.02(108)$ & $0.32 \pm 0.03(408)$ \\
\hline Oct & $0.25 \pm 0.02(152)$ & $0.36 \pm 0.03$ & $0.27 \pm 0.05(50)$ & $0.31 \pm 0.03(292)$ \\
\hline Nov & - & $0.35 \pm 0.03(200)$ & $0.26 \pm 0.02(49)$ & $0.31 \pm 0.03(296)$ \\
\hline
\end{tabular}


2004, such analyses were only possible for proteins in eggs of this same population (Table 3 ). Protein content in eggs from the southern population differed slightly from the beginning (July/August) to the end (October/November) of the spawning season in 2003 ( $t$-test, $\mathrm{p}=0.023)$; however, this decrease in protein concentrations was not significant in 2004 ( $t$-test, $p=0.452$ ) (Fig. 2). Protein concentrations from the northern population in 2004, although variable at the beginning of the season, showed a clear decrease trend throughout the 3 mo of data available.

The highest concentrations of total lipids in eggs from the northern area occurred at the beginning (July) of the spawning season in 2004. In the southern area, higher lipid concentrations also occurred early in the season, but their highest values occurred in August of both years (Fig. 2), decreasing later towards the end of the season. TAG and cholesterol concentrations per milligram of egg dry weight from the southern populations showed fairly similar trends of a decrease in concentrations throughout the spawning season in both years. In the northern population this trend was not observed.

In 2003, eggs from the northern area had successful hatchings from about 62 to $89 \%$, and the maximum success coincided with the dates of maximum egg size (September; Table 4). During 2004, in turn, hatching success for eggs of both populations tended
Table 2. Engraulis ringens. Regression parameters between egg volume and month (beginning in July, $t=0,1,2,3$, and 4) off northern (Iquique) and southern (Talcahuano) Chile during the winter spawning seasons of 2003 and 2004. All $\mathrm{p}$-values are highly significant $(\mathrm{p}<0.001)$

\begin{tabular}{|lcccc|}
\hline & Intercept & Slope & $\mathrm{N}$ & $\mathrm{p}$ \\
\hline North & & & & \\
2003 & 0.380 & -0.012 & 305 & $2.46 \times 10^{-16}$ \\
2004 & 0.367 & -0.010 & 426 & $5.219 \times 10^{-20}$ \\
South & & & & \\
2003 & 0.414 & -0.006 & 600 & $1.50 \times 10^{-6}$ \\
2004 & 0.377 & -0.006 & 1813 & $2.025 \times 10^{-34}$ \\
\hline
\end{tabular}

Table 3. Engraulis ringens. Mean concentration, standard deviation, and number of replicates utilized (in parentheses) for total protein, total lipid, triacylglycerides (TAG), and cholesterol in anchoveta eggs collected off northern (Iquique) and southern (Talcahuano) Chile during the winter spawning seasons of 2003 and 2004. -: no data

\begin{tabular}{|c|c|c|c|c|}
\hline & $\begin{array}{l}\text { Total protein } \\
\left(\mu \mathrm{g} \text { protein } \mathrm{mg}^{-1}\right. \\
\text { egg DW) }\end{array}$ & $\begin{array}{c}\text { Total lipid } \\
\left(\mu g_{\text {lipids mg }}^{-1}\right. \\
\text { egg DW) }\end{array}$ & $\begin{array}{c}\text { TAG } \\
\left(\mu g \text { TAG } \mathrm{mg}^{-1}\right. \\
\text { egg DW) }\end{array}$ & $\begin{array}{c}\text { Cholesterol } \\
(\mu g \text { cholesterol } \\
\mathrm{mg}^{-1} \text { egg DW) }\end{array}$ \\
\hline \multicolumn{5}{|c|}{ South, 2003} \\
\hline Jul & $215.48 \pm 41.76(4)$ & $391.32 \pm 175.50$ & $18.89 \pm 7.36(2)$ & $8.32 \pm 3.27(3)$ \\
\hline Aug & $249.26 \pm 81.00(9)$ & $894.29(1)$ & $15.18 \pm 9.05(7)$ & $8.62 \pm 5.25(7)$ \\
\hline Sep & $203.14 \pm 49.66$ & $404.31 \pm 253.46(2)$ & $9.09 \pm 1.46(2)$ & $3.76 \pm 3.72(2)$ \\
\hline Oct & $222.81 \pm 23.29(2)$ & $373.80(1)$ & $1.98(1)$ & $3.74(1)$ \\
\hline Nov & $231.50 \pm 11.66$ & $217.39 \pm 121.89(3)$ & $2.82 \pm 0.41(2)$ & $8.79 \pm 3.73(3)$ \\
\hline \multicolumn{5}{|c|}{ North, 2004} \\
\hline Jul & $202.65 \pm 95.45(4)$ & $147.32 \pm 87.23(7)$ & $10.86 \pm 4.12(4)$ & $2.95 \pm 0.99(3)$ \\
\hline Aug & $154.20 \pm 56.07(2)$ & $110.98 \pm 56.32(2)$ & $13.25 \pm 3.14(7)$ & $4.67 \pm 2.11(6)$ \\
\hline Sep & $122.82 \pm 45.81(3)$ & $118.96 \pm 95.38(1)$ & $12.64 \pm 4.16(2)$ & $5.34 \pm 4.49(2)$ \\
\hline Oct & - & - & - & - \\
\hline \multicolumn{5}{|c|}{ South, 2004} \\
\hline Jul & $220.05(1)$ & $117(1)$ & $23.81(1)$ & $9.71(1)$ \\
\hline Aug & $200.91 \pm 34.85$ & $341.34 \pm 193.60(2)$ & $34.75 \pm 2.37(2)$ & $5.77 \pm 0.54$ \\
\hline Sep & - & $196.77 \pm 12.60(2)$ & $17.36 \pm 6.99(2)$ & $4.80 \pm 1.19(2)$ \\
\hline Oct & $232.72 \pm 9.47(2)$ & $190.33 \pm 22.12(2)$ & $23.47 \pm 6.24$ & $4.96 \pm 2.07(2)$ \\
\hline Nov & $198.57(1)$ & - & - & - \\
\hline
\end{tabular}

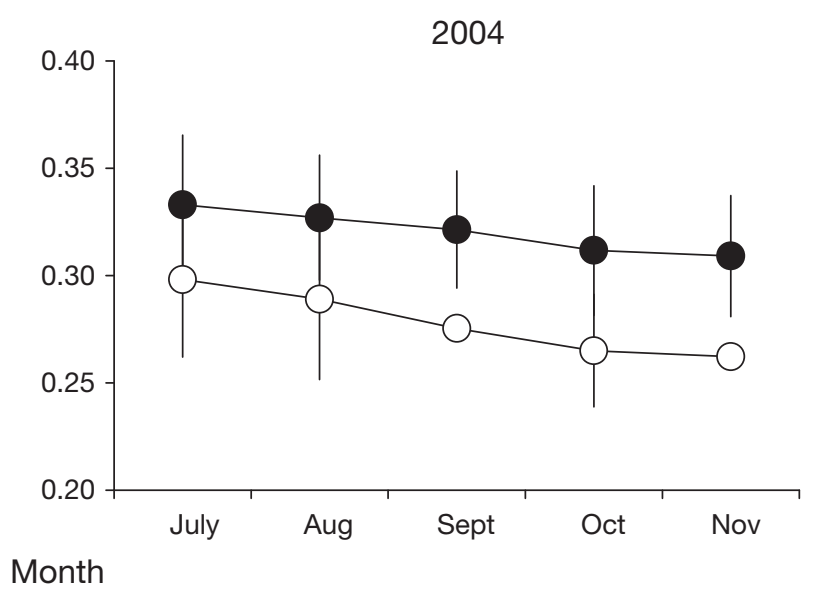

Month

Fig. 2. Engraulis ringens. Intra-seasonal variation in anchoveta egg volume $\left(\mathrm{mm}^{3}\right)$ during the 2003 and 2004 spawning seasons off northern and southern Chile 
to decrease as the spawning season progressed, with the values of hatching success registered for the southern populations being higher than those for the northern eggs (Fig. 3).

\section{Inter-population variations}

Results from $t$-tests for comparisons of slopes and intercepts (given in Table 2) showed significant ( $\mathrm{p}<$ 0.05) differences in egg volume between populations as the spawning season progressed in both years $\left(t_{\text {calc }}\right.$ slopes $=3.67$ and $3.12 ; t_{\text {calc }}$ intercepts $=11.97$ and 7.99 for 2003 and 2004, respectively). Within each zone, intercepts and slopes did not vary between years in the northern population $\left(t_{\text {calc }}=1.42\right.$ and 1.02 for slopes and intercepts, respectively); however, a significant difference in the intercepts $\left(t_{\text {calc }}=0.65\right)$, but not in the slopes $\left(t_{\text {calc }}=9.87\right)$, was detected in the southern population.

When mean values are compared, eggs spawned by the southern population were larger than those

Table 4. Engraulis ringens. Mean percentage of hatching success for anchoveta eggs collected off northern (Iquique) and southern (Talcahuano) Chile during the winter spawning seasons of 2003 and 2004. -: no data

\begin{tabular}{|c|c|c|c|}
\hline \multirow{2}{*}{ Month } & \multirow{2}{*}{$\begin{array}{c}2003 \\
\text { North }\end{array}$} & \multicolumn{2}{|c|}{-2004} \\
\hline & & North & South \\
\hline Jul & $85.0 \pm 12.1$ & $65.6 \pm 26.6$ & - \\
\hline Aug & $61.8 \pm 17.8$ & $55.3 \pm 26.5$ & $99.5 \pm 0.7$ \\
\hline Sep & $88.9 \pm 14.3$ & $38.6 \pm 15.0$ & $78.5 \pm 16.7$ \\
\hline Oct & $71.5 \pm 36.3$ & $31.2 \pm 35.2$ & $69.3 \pm 20.0$ \\
\hline Nov & - & - & 63.2 \\
\hline
\end{tabular}

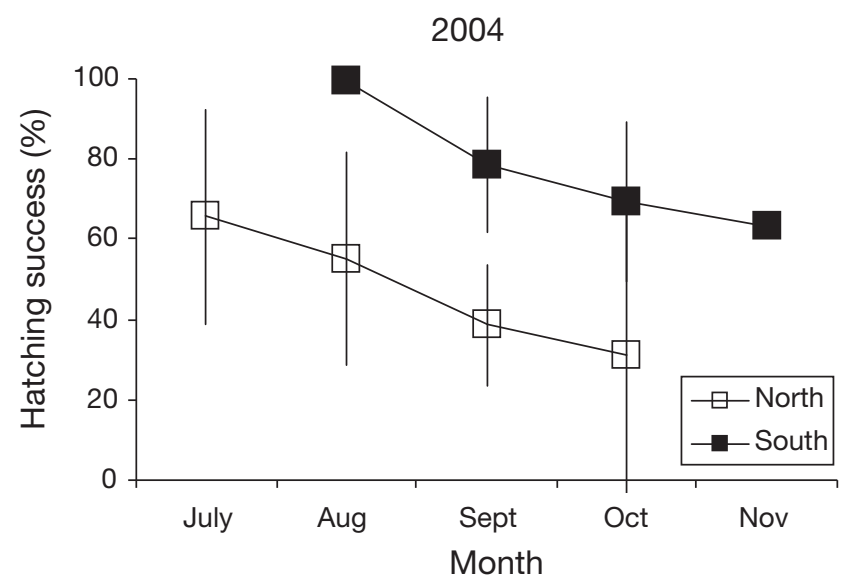

Fig. 3. Engraulis ringens. Intra-seasonal variation in hatching success (\%) during the 2003 and 2004 spawning seasons off northern and southern Chile from the northern area in both years (Kruskall-Wallis, $\left.H_{2003(1, \mathrm{~N}=905)}=558 ; H_{2004(1, \mathrm{~N}=1823)}=439\right)$. Differences in egg size also occurred inter-annually in each population (Kruskal-Wallis $H_{\text {North }(1, \mathrm{~N}=732)}=36.24$, $\mathrm{p}<0.001$; $\left.H_{\text {South }(1, \mathrm{~N}=2413)}=546.98, \mathrm{p}<0.001\right)$ (Fig. 4).

Comparisons of biochemical characteristics of the eggs between populations were carried out only for 2004 because these characteristics were not determined for the northern population in 2003. All egg characteristics showed the same trend of higher values in the southern populations (Fig. 4). This trend was statistically significant for egg volume $(t$-test, $\mathrm{p}<$ $0.001)$, total lipids ( $t$-test, $\mathrm{p}=0.02)$, and TAG ( $t$-test, $\mathrm{p}<0.001$ ), but not for mean egg dry weight ( $t$-test, $\mathrm{p}=$ $0.136)$, total protein ( $t$-test, $\mathrm{p}=0.81$ ), or cholesterol ( $t$-test, $\mathrm{p}=0.18)$.

\section{Hatching success, egg size, and biochemical composition relationships}

In order to evaluate the potential relationship between hatching success, egg size, and the different biochemical characteristics of the eggs over their entire range of variability, data obtained in 2004 from the northern and southern populations were pooled (Fig. 5). Positive relationships were observed between hatching success (HS, \%) and egg size $(V)$ $\left(\mathrm{HS}=-212.91+921.04 V_{;} \mathrm{R}^{2}=0.86 ; \mathrm{p}<0.001, \mathrm{~N}=9\right)$. Lipid $(L)\left(\mathrm{HS}=26.51+0.22 L ; \mathrm{R}^{2}=0.84 ; \mathrm{p}<0.05, \mathrm{~N}=\right.$ $6)$ and TAG concentrations (HS $=32.87+1.86 \mathrm{TAG} ; \mathrm{R}^{2}$ $=0.67 ; \mathrm{p}<0.05, \mathrm{~N}=6$ ) were also positive and significantly correlated. Although the relationship between total proteins (Pr) and hatching success followed the same trend (positive relationship), it was not significant $\left(\mathrm{HS}=0.34+1.81 \mathrm{Pr}_{;} \mathrm{R}^{2}=0.46 ; \mathrm{p}<0.14, \mathrm{~N}=6\right.$ ).

\section{Batch and relative fecundity}

Mean batch fecundity estimated in females from the northern population was higher (13425 and 10087 eggs in 2003 and 2004, respectively) than in southern females (6491 and 8325 eggs in 2003 and 2004, respectively) during both years. The same trend was observed in relative fecundity with 562 and 412 eggs $\mathrm{g}^{-1}$ in northern females and 398 and 390 eggs $\mathrm{g}^{-1}$ in southern females, in 2003 and 2004, respectively (Fig. 6). The regressions between female weight and batch fecundity were all significant $(p<0.001)$ for all years and areas, and no differences were detected between years in each zone (Table 5). Accordingly, we pooled the data for both years and compared the regressions between zones. Significant differences were observed between the slopes of the pooled re- 

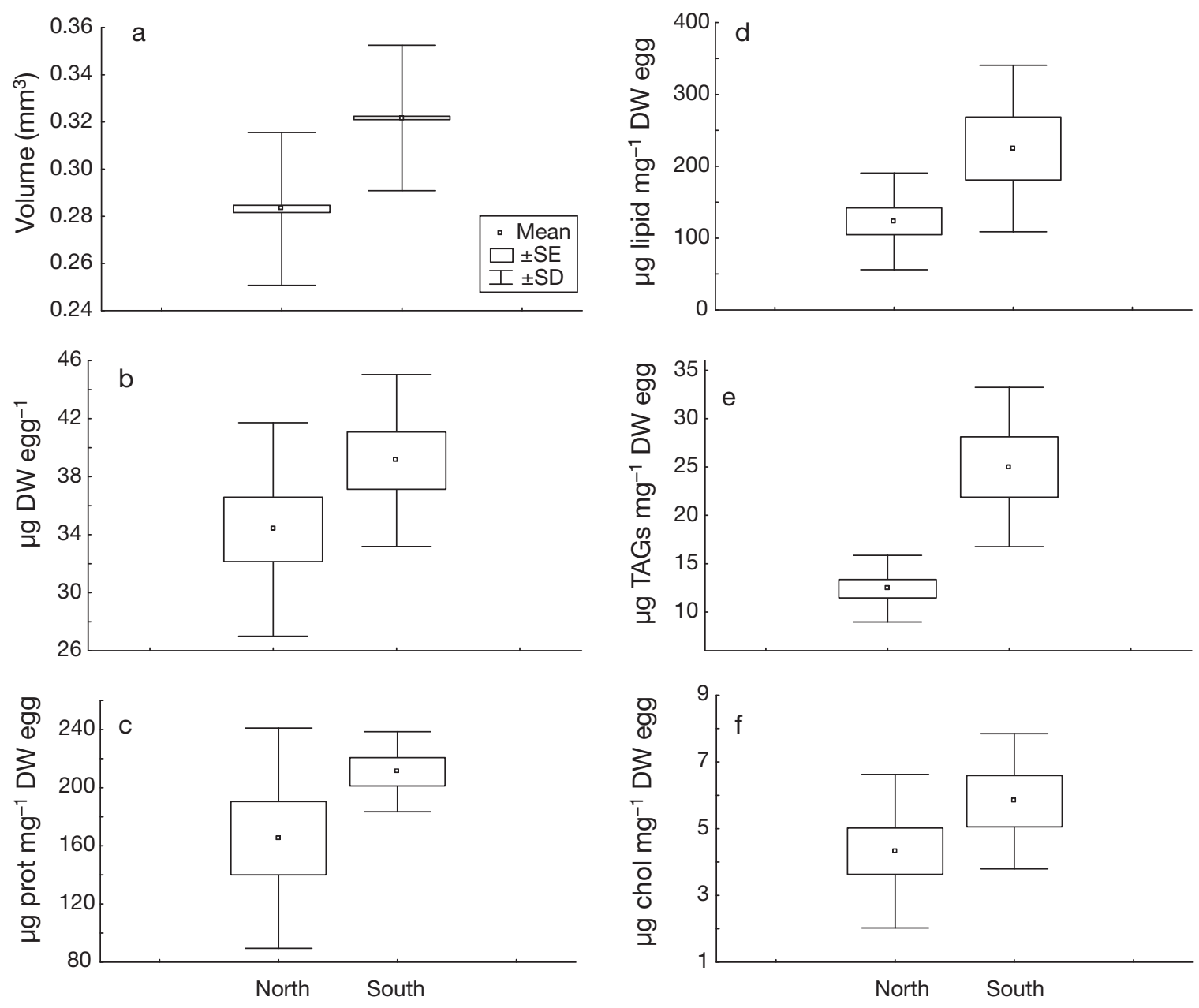

Fig. 4. Engraulis ringens. Mean (a) egg volume, (b) egg dry weight (DW), and (c) protein, (d) lipid, (e) triacylglycerides (TAG), and

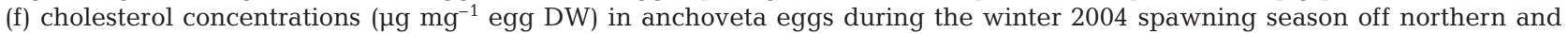
southern Chile

gressions ( $t$-slope test: $\left.t=2.76 ; t_{0.05(2), 359}=1.97\right)$, the slope values for the northern females being higher than those for their southern counterparts.

\section{Environmental conditions}

A clear seasonal pattern in environmental characteristics was observed for both years and at both locations. The highest sea surface temperatures and most frequent southern, upwelling-favorable winds occurred in summer, and the lowest temperatures and least frequent upwelling winds occurred in winter, coinciding with the anchoveta spawning season (Fig. 7). The seasonal changes in environmental conditions were more marked at the southern latitudes, especially in wind-related characteristics; from sum- mer to winter the wind directions changed from south to north and the wind intensity increased from about $3 \mathrm{~m} \mathrm{~s}^{-1}$ daily to $>5 \mathrm{~m} \mathrm{~s}^{-1}$.

Besides the range in seasonal fluctuations, the magnitude of the environmental variables between sites was also different. Sea surface temperature was always about 3 to $4^{\circ} \mathrm{C}$ higher in the more northern area (Iquique). For most of the year, winds off Iquique were from the southern quadrants, inducing year-round coastal upwelling; in the southern area, southern winds only predominated in spring and summer. Finally, windinduced turbulence due to strong wind events that might have mixed the water column did not occur off Iquique, but they did occur off the southern location. During the main winter anchoveta spawning season, therefore, the environmental conditions for the early life stages were less harsh in the northern than in the southern zone. 


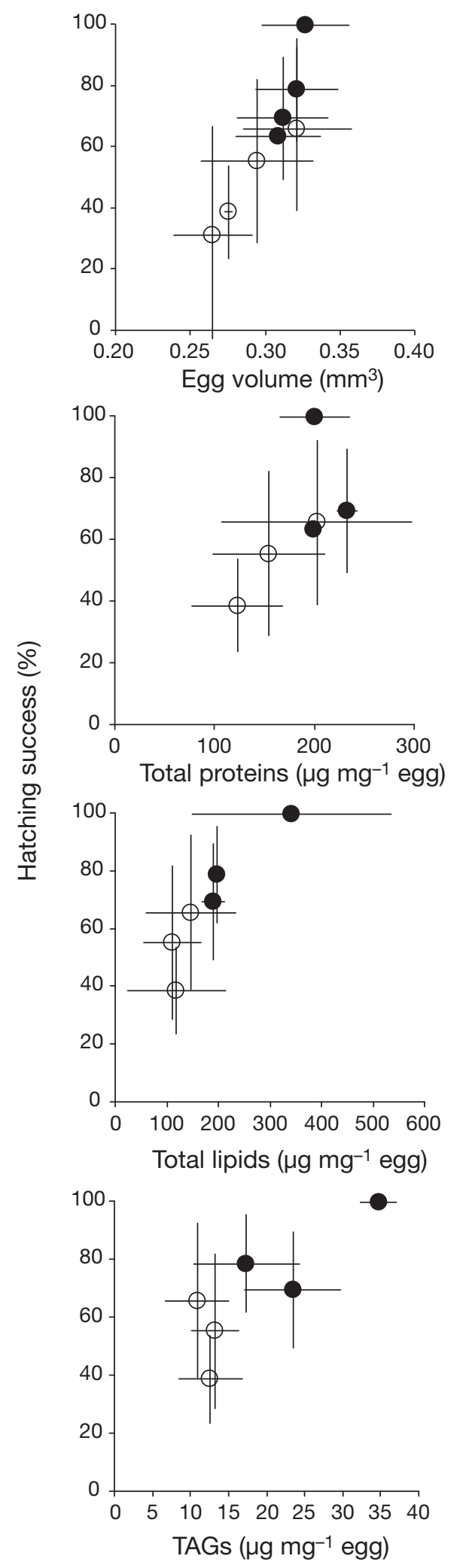

Fig. 5. Engraulis ringens. Relationship between hatching success (\%) and egg volume in 2003 and 2004, and between hatching success and protein and lipid (including triacylglycerides, TAG) concentrations ( $\mu \mathrm{g} \mathrm{mg}^{-1}$ egg) during the 2004 winter spawning season for pooled northern $(\mathrm{O})$ and southern $(\mathbf{O})$ eggs
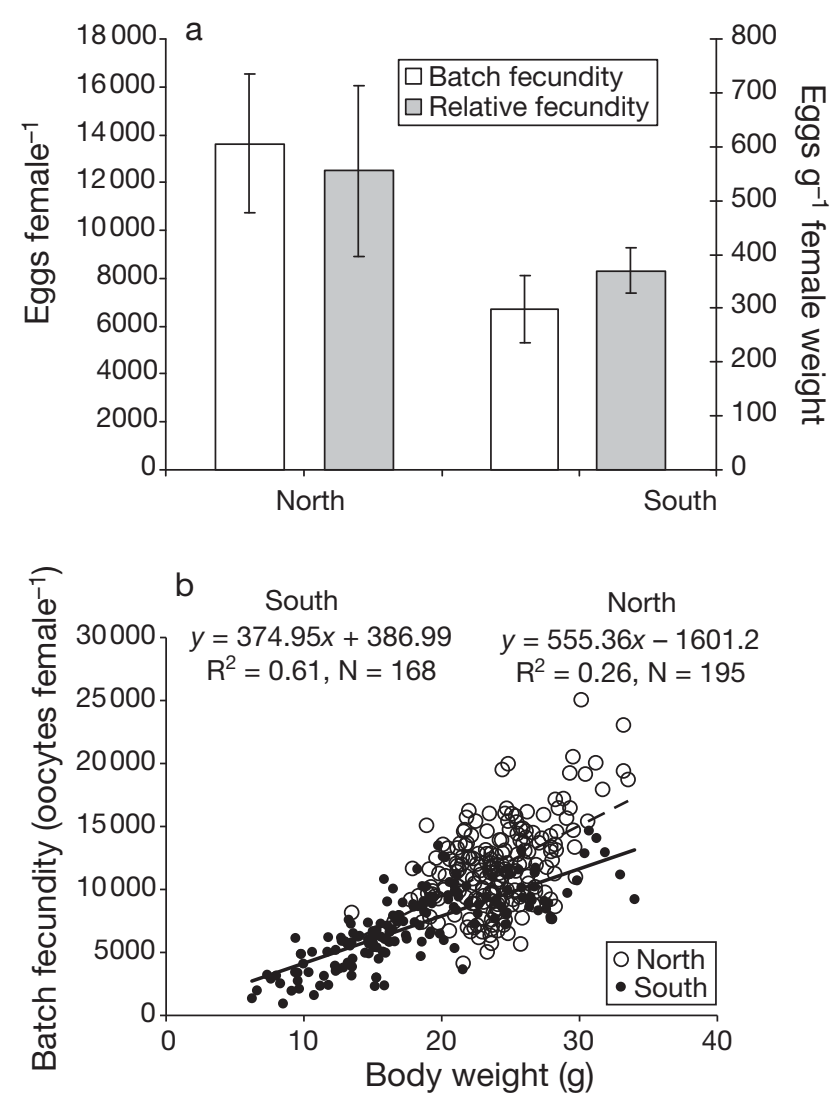

Fig. 6. Engraulis ringens. (a) Mean batch (eggs female ${ }^{-1}$ ) and relative fecundity (eggs $\mathrm{g}^{-1}$ female weight) of anchoveta females during the peak spawning months (August) between 2002 and 2005 off northern and southern Chile. (b) Regression between batch fecundity and body weight for females from the north and south populations (2003 and 2004 pooled data)

\section{DISCUSSION}

The reproductive strategies proposed for anchovies living under different environmental conditions have traditionally included rapid growth rates, young age of maturity, and high fecundity associated with abundant but small and energetically cheap eggs. In our study, we show that anchoveta Engraulis ringens egg size is smaller off northern than off southern Chile, that the egg size declines during the reproductive season in both populations, and that the inter-population differences remain almost unaltered throughout the spawning season. Seasonal variations in egg size have also been reported for several small pelagic species with protracted or repeated spawning periods such as Engraulis anchoita (Ciechomski 1973), Scombrus scombrus (Ware 1977), Engraulis mordax (Hunter \& Leong 1981), Encrasicholina purpurea (Clarke 1989), and Sardinops sagax (Claramunt et al. 1994). Changes in 
egg size during the spawning season have also been reported for the anchoveta $E$. ringens, but only in the higher latitude population (Castro et al. 2001, LlanosRivera \& Castro 2004). For this species, recent reports also show that the initial differences in egg size

Table 5. Engraulis ringens. Regression parameters between weight and batch fecundity in northern (Iquique) and southern (Talcahuano) female anchoveta during August 2003 and 2004. All p-values highly significant $(p<0.001)$

\begin{tabular}{|lrrrrrc|}
\hline & Intercept & Slope & $\mathrm{N}$ & $\mathrm{R}^{2}$ & $F$ & $\mathrm{p}$ \\
\hline North & & & & & & \\
2003 & -1237.7 & 615.8 & 99 & 0.54 & 114.6 & $4.02 \times 10^{-18}$ \\
2004 & -4164.1 & 584.2 & 96 & 0.20 & 23.6 & $4.74 \times 10^{-6}$ \\
South & & & & & & \\
2003 & 122.0 & 395.1 & 100 & 0.58 & 134.5 & $4.34 \times 10^{-20}$ \\
2004 & 600.2 & 360.9 & 68 & 0.56 & 85.3 & $1.68 \times 10^{-13}$ \\
\hline
\end{tabular}

between the northern and southern populations off Chile propagate to the following exogenous-feeding larval stage (post yolk sac larvae) (Llanos-Rivera \& Castro 2006). In both populations, initial winter egg sizes were highly correlated with larval length at hatching, yolk sac volume at hatching, and larval length at yolk absorption; all these traits may positively affect the survival chances of the young larvae. Since larger egg sizes occurred in those individuals spawned in the middle of winter, when the environmental conditions were harshest, especially in the southern populations, we propose that variations in the egg volume may represent an indirect maternal effect to facilitate subsequent larval survival during the winter season.
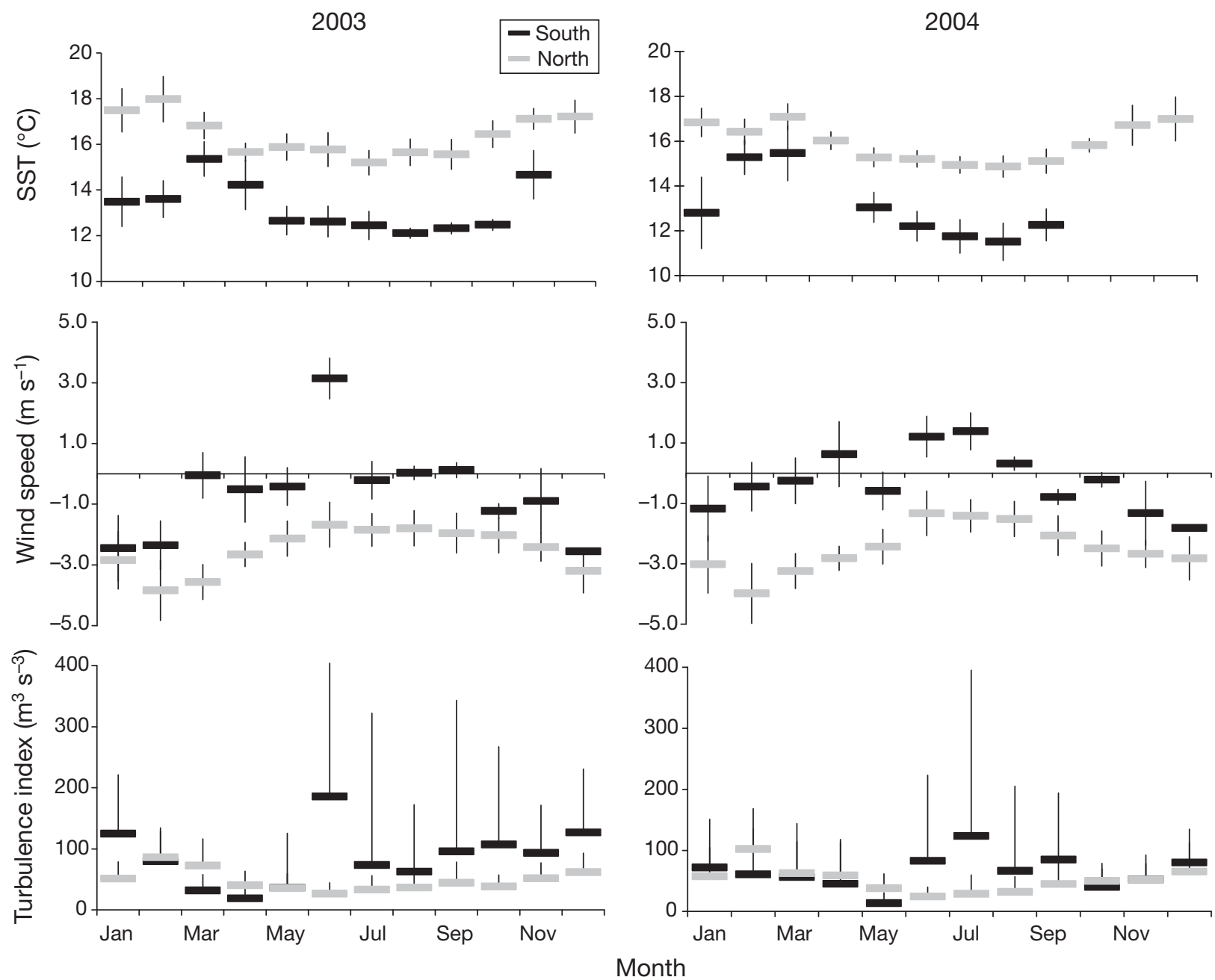

Fig. 7. Engraulis ringens. Sea surface temperature $\left(\mathrm{SST},{ }^{\circ} \mathrm{C}\right)$, wind speed $\left(\mathrm{N}-\mathrm{S}\right.$ component, $\left.\mathrm{m} \mathrm{s}^{-1}\right)$, and turbulence index $\left(\mathrm{m}^{3} \mathrm{~s}^{-3}\right)$ in the northern and southern spawning areas in 2003 and 2004. Negative wind speeds (from the south) induce upwelling (see 'Results: Environmental conditions'). Vertical lines are standard deviations 
Given the usual positive relationship between fecundity and female size, females have to be larger and possess larger ovaries able to contain more and larger oocytes. Batch fecundity (number of eggs spawned per batch per female) and relative fecundity (number of eggs spawned per female weight) during the peak spawning season were lower in the southern than in the northern population. In other words, the cost for spawning larger eggs in the southern population seems to be a reduction in the female's batch fecundity. Batch fecundity and egg size, therefore, represent traits in reproductive strategy that clearly differ between anchoveta populations along the Humboldt Current and that probably vary according to the environmental characteristics of the different reproductive habitats.

Analyses of the biochemical characteristics of eggs during the spawning season also showed differences between populations. Total lipid contents and TAGs occurred in much higher concentrations in the southern eggs that in those from the northern stock. Lipids are some of the most important nutritional components of broodstock that affect egg quality (Rainuzzo et al. 1997). Lipids are used as an energetic source for metabolism during embryonic development, and TAGs have been cited as the most common form of energy stored in eggs, as well as in later life stages, of most marine fish (Cowey et al. 1985). During starvation, TAGs are used before phospholipids (Sargent et al. 1999), which are important structural membrane components, although the latter may also be important sources of energy during embryonic development in species with less TAG (Tocher et al. 1985, Fraser et al. 1988, Falk-Petersen et al. 1989, Rainuzzo et al. 1992). Thus, our results showing higher lipid and TAG contents in eggs produced during winter in the southern area, where temperatures are lower and, thus, embryonic developmental times are longer (Tarifeño et al. 2007), and feeding conditions are poorer (i.e. less plankton production, strong turbulence, lower temperature), seem to support the idea that increased lipid and TAG concentrations in eggs may be beneficial for embryos and for later larval survival.

Seasonal changes in the biochemical composition of fish eggs have also been reported for other clupeiforms in upwelling areas. In Sardina pilchardus eggs, for instance, Riveiro et al. $(2000,2004)$ reported that the organic content (lipids, carbohydrates, proteins) decreased as the spawning season progressed from winter to mid-spring off the Iberian Peninsula. This decrease was accompanied by an increase in the environmental temperature and seston in the water column (a proxy for larval food) and was interpreted as part of a reproductive strategy in which better quality eggs were spawned under winter conditions (low tempe- rature, less abundant larval food). In S. pilchardus, proteins correlated negatively with embryonic developmental times and, hence, were proposed to be potentially more important than lipids and carbohydrates, because eggs with higher protein concentrations could compensate for the lower temperature at the beginning of the cold months that retarded development. Our results coincided almost entirely with those reported for $S$. pilchardus. In Engraulis ringens, estimated developmental times and the tendency for protein concentrations to decrease also changed during the spawning season, although the latter was not significant.

High intra-seasonal variability was observed in our hatching success estimates for both areas. Despite this variability, a clearly decreasing trend in hatching success occurred as the spawning season progressed. Lipids and TAGs also showed the same trend over the season and were highly correlated with hatching success when the entire dataset from both areas was pooled. The biochemical content of the eggs, which is determined while energy is accumulated and allocated to oogenesis (Chambers et al. 1989), therefore, seems to play an important role in determining the survival chances of the different cohorts spawned during the season. In periods of the reproductive season in which egg quality is high (i.e. high lipid contents), hatching success is also high, independent of whether this occurs in the northern or southern population. These results are particularly interesting, especially when considering inter-annual variations, and they might explain the abrupt changes in recruitment observed from one year to another despite large reductions in biomass. This explanation, therefore, is an alternative to the traditional hypotheses dealing with improved habitat conditions for larval growth and survival proposed to explain population booms in clupeiforms.

The anchoveta life cycle in the southern distribution area along the Humboldt Current includes a series of sequential events (winter reproduction, spring-early summer juvenile growth, late summer-early fall lipid accumulation) and a reproductive strategy based on winter spawning. Three non-independent hypotheses may explain the timing of winter reproduction: (1) winter spawning facilitates egg and larval retention at the coast, as a result of northern winds inducing shoreward egg and larval transport (Castro et al. 2000, Castro 2001); (2) winter spawning may be beneficial for larvae and juveniles, allowing them to take advantage of the high plankton production in spring and early summer when juvenile anchoveta reach high growth rates (Cubillos et al. 2001); and (3) winter spawning may be favored as result of reserves accumulated in late summer for winter reproduction (Hunter \& Leong 1981). All 3 of these hypotheses involve different pro- 
cesses in the life history of the fish, but they all finally rely on the premise that acceptable offspring survival can be achieved during the winter spawning months. Since the feeding environment seems not to be the best for young larval success (less food available than in spring and summer upwelling months, higher water column turbulence due to winter storms), the parental population has to provide mechanisms to facilitate egg and young larval survival under these environmental conditions. Accordingly, maternal influences such as those reported in the present study should not be surprising, especially in areas close to the species' southern distribution limit.

In the present study, we were interested in assessing early life-history characteristics that vary along the species distributional range in response to latitudinal changes in environmental conditions. Also, we were interested in determining whether differences exist in the early life-history traits of individuals spawned in different months of the spawning season. Our overall results from this and previous studies identified several egg and larval characteristics that vary between populations located at different latitudes. In some cases, these characteristics were not independent of each other, but were derived from an initial difference in egg volume. Additionally, our results showed that differences also existed in the biochemical characteristics present in the egg stage, such as lipids. When considered within the context of the normal environmental conditions faced by the population at different latitudes, the importance of these early life-history traits becomes more apparent. High turbulence, low temperature, and lower food availability are typical environmental conditions of early winter in the southern spawning season. Alternatively, low turbulence, higher temperature, and high food availability are often the case in the spawning area of the northern population. In other words, larger egg sizes and increased lipid contents, with the consequent reduction in batch fecundity, seem to be the mechanisms by which the survival of young offspring is facilitated in the more adverse southern, winter environmental conditions. These egg characteristics are tailored to the reproductive system of the adult female, and, as such, these characteristics represent one clear type of maternal influence on the early life-history traits of the anchovies that might enable rapid changes in population densities in years of improved habitat conditions, either for females or young stages.

Acknowledgements. Funding for the present study was provided by FONDECYT (Grants 1030819 and 1070502 to L.R.C. and G.C.). We acknowledge M. Braun (IFOP) and L. Cubillos (U. de Concepción) for providing the samples of hydrated females for partial fecundity estimations. A.L.-R. and M.C.K. were supported by the Graduate School of the
Universidad de Concepción, and M.C.K. is currently the beneficiary of a CONICYT Doctoral Fellowship. We acknowledge collaboration in different phases of this research from the following: M. Gonzalez (MS) of the Department of Human Immunology, U. de Concepción, for laboratory facilities; Drs R. Quinones and R. Gonzalez for sharing equipment at the Coastal Marine Station in Dichato, U. de Concepción; Dr. E. Tarifeño for valuable comments made during the study; $\mathrm{S}$. Soto and students from LOPEL and U. Arturo Part for help in the field work; Servicio Hidrografico y Oceanografico de la Armada (SHOA) for SST data; Dirección Meteorológica de Chile for wind data; the crew of the RV 'Kay Kay'; and J. Marileo for maintaining the facilities at the Coastal Marine Station in Dichato, U. de Concepción.

\section{LITERATURE CITED}

Bagenal TB (1971) The interrelation of the size of fish eggs, the date of spawning and the production cycle. J Fish Biol 3:207-219

Blaxter J, Hempel G (1963) The influence of egg size on herring larvae (Clupea harengus). J Cons Int Explor Mer 28:211-240

> Blaxter JHS, Hunter JR (1982) The biology of clupeoid fishes. Adv Mar Biol 20:1-223

> Bligh EG, Dyer WJ (1959) A rapid method of total lipid extraction and purification. Can J Biochem Physiol 37:911-917

Castro LR (2001) Studies on environmental conditions and larval survival of the southernmost anchoveta stock of the Humboldt Current during the winter spawning season. GLOBEC Int Newsl 7:15-17

Castro LR, Salinas GR, Hernández EH (2000) Environmental influences on winter spawning of the anchoveta Engraulis ringens off Central Chile. Mar Ecol Prog Ser 197:247-258

Castro L, Llanos A, Blanco JL, Tarifeño E, Escribano R, Landaeta M (2001) Latitude variations in spawning habitat characteristics: influence on the early life history traits of the anchoveta, Engraulis ringens, off northern and central Chile. GLOBEC Rep 16:42-45

Chambers RC (1997) Environmental influences on egg and propagule sizes in marine fishes. In: Chambers RC, Trippel EA (eds) Early life history and recruitment of fish populations. Chapman \& Hall, London, p 63-102

Chambers RC, Waiwood KG (1996) Maternal and seasonal differences in egg sizes and spawning characteristics of captive Atlantic cod, Gadus morhua. Can J Fish Aquat Sci 53:1986-2003

Chambers RC, Leggett W, Brown J (1989) Egg size, female effects, and correlations between early life history traits of capelin, Mallotus villosus: an appraisal at the individual level. Fish Bull (Wash DC) 87:515-523

Ciechomski J (1973) The size of the egg of the Argentine anchovy Engraulis anchoita in relation to the season of the year of spawning. J Fish Biol 5:393-398

Claramunt G, Herrera G, Pizarro P (1994) Producción potencial anual de huevos por tallas en Sardinops sagax (Jenyns, 1842) del norte de Chile. Rev Biol Mar 29: 211-233

Clarke TA (1989) Seasonal differences in spawning, egg size, and early development time of the Hawaiian anchovy of nehu, Encrasicholina purpurea. Fish Bull (Wash DC) 87: 593-600

Cowey CB, Mackie AM, Bell JG (1985) Nutrition and feeding in fish. Academic Press, London

Cubillos LA, Arcos DF, Bucarey DA, Canales MT (2001) Seasonal growth of small pelagic fish off Talcahuano, Chile $\left(37^{\circ} \mathrm{S}, 73^{\circ} \mathrm{W}\right)$ : A consequence of their reproductive 
strategy to seasonal upwelling? Aquat Living Resour 14: 115-124

Daoulas C, Economou AN (1986) Seasonal variation of egg size in the sardine, Sardina pilchardus Walb., of the Saronikos Gulf: causes and a probable explanation. J Fish Biol 28:449-457

Falk-Petersen S, Sargent JR, Fox C, Falk-Petersen IB, Haug T, Kjørsvik E (1989) Lipids in Atlantic halibut (Hippoglossus hyppoglossus) eggs from planktonic sampes in northern Norway. Mar Biol 101:553-556

Fraser AJ, Gamble JC, Sargent JR (1988) Changes in lipid content, lipid class composition of developing eggs of cod (Gadus morhua). Mar Biol 99:307-313

Fisher W (1958) Huevos, crias y larvas de anchoveta Engraulis ringens Jenyns. Rev Biol Mar 8:11-124

Fyhn HJ (1989) First feeding of marine fish larvae: Are free amino-acids the source of energy? Aquaculture 80: 111-120

Hernández E, Castro L (2000) Larval growth of the anchoveta Engraulis ringens during the winter spawning season off central Chile. Fish Bull (Wash DC) 98:704-710

Hunter JR, Goldberg SR (1980) Spawning incidence and batch fecundity in northern anchovy, Engraulis mordax. Fish Bull (Wash DC) 77:641-652

Hunter JR, Leong RJH (1981) The spawning energetics of female northern anchovy, Engraulis mordax. Fish Bull (Wash DC) 79:215-230

Kamler E (1992) Early life history of fish. An energetics approach. Fish and fisheries sciences 4. Chapman \& Hall, London

Lahnsteiner F, Patarnello P (2005) The shape of the lipid vesicle is a potential marker for egg quality determination in the gilhead seabream, Sparus aurata, and in the sharpsnout seabream, Diplodus puntazzo. Aquaculture 246:423-435

Llanos-Rivera A, Castro LR (2004) Latitudinal and seasonal egg size variations of the anchoveta Engraulis ringens off the Chilean Coast. Fish Bull (Wash DC) 102:207-212

Llanos-Rivera A, Castro LR (2006) Inter-population differences in temperature effects on Engraulis ringens yolk-sac larvae. Mar Ecol Prog Ser 312:245-253

Lowry OH, Rosebrough NJ, Farr AL, Randall RJ (1951) Protein measurement with the folin-phenol reagent. J Biol Chem 193:265-275

Marteinsdottir G, Steinarsson A (1998) Maternal influence on the size and viability of Icelandic cod Gadus morhua eggs and larvae. J Fish Biol 52:1241-1258

Pickova J, Dutta PC, Larson PO, Kiessling A (1997) Early

Editorial responsibility: Otto Kinne,

Oldendorf/Luhe, Germany embryonic cleavage pattern, hatching success, and egglipid fatty acid composition: comparison between two cod stocks. Can J Fish Aquat Sci 54:2410-2416

Plaza G, Claramunt G, Herrera G (2002) An intra-annual analysis of intermediate fecundity, batch fecundity and oocyte size of ripening ovaries of Pacific sardine Sardinops sagax in northern Chile. Fish Sci 68:95-103

Rainuzzo JR, Reitan KI, Jorgensen L (1992) Comparative study on the fatty acid and lipid composition of four marine fish larvae. Comp Biochem Physiol 103B:21-26

Rainuzzo JR, Reitan KI, Olsen Y (1997) The significance of lipids at early stages of marine fish: a review. Aquaculture 155:103-105

> Rideout RM, Trippel EA, Litvak MK (2005) Effects of egg size, food supply and spawning time on early life history success of haddock Melanogrammus aeglefinus. Mar Ecol Prog Ser 285:169-180

> Rijnsdorp AD, Vingerhoed B (1994) The ecological significance of geographical and seasonal differences in egg size in Solea solea (L.). Neth J Sea Res 32:255-270

Riveiro I, Guisande C, Lloves M, Maneiro I, Cabanas JM (2000) Importance of parental effects on larval survival in Sardina pilchardus. Mar Ecol Prog Ser 205:249-258

Riveiro I, Guisande C, Maneiro I, Vergara AR (2004) Parental effects in the European sardine Sardine pilchardus. Mar Ecol Prog Ser 274:225-234

Sargent J, McEvoy L, Estevez A, Bell G, Bell M, Henderson J, Tocher D (1999) Lipid nutrition of marine fish during early development: current status and future directions. Aquaculture 179:217-229

Soto SA, Claramunt G, Escribano R (2005) Temperaturedependent development rates of eggs of the southern anchoveta Engraulis ringens. GLOBEC Rep 21:51-54

Tarifeño E, Carmona M, Llanos-Rivera A, Castro LR (2007) Temperature effects on the anchoveta Engraulis ringens egg development: Do latitudinal differences occur? Environ Biol Fish 81:387-395

Thresher RE (1984) Reproduction in reef fishes. T.F.H. Publications, Neptune City, NJ

Tocher DR, Fraser AJ, Sargent JR, Gamble JC (1985) Lipid class composition during embryonic and early larval development in Atlantic herring (Clupea harengus L.). Lipids 20:84-89

Ware DM (1977) Spawning time and egg size of Atlantic mackerel, Scomber scombrus, in relation to the plankton. J Fish Res Board Can 34:2308-2315

Submitted: September 22, 2007; Accepted: January 8, 2009 Proofs received from author(s): March 31, 2009 